\title{
Task, formulaic language, and role play for developing ESL students' academic language
}

\author{
Chandrasena Mandalasamy Rajeswaran
}

Department of English, Dr MGR Educational and Research Institute, Chennai - 600 095, India

\begin{tabular}{|c|c|c|}
\hline \multirow{2}{*}{\multicolumn{3}{|c|}{$\begin{array}{l}\text { The effectiveness of task, formulaic language, and role play in facilitating uninhibited } \\
\text { communication of ESL learners is beyond doubt. This quantitative empirical research employed } \\
\text { a role play communicative assessment and a writing assessment to assess the efficacy of the } \\
\text { combination of task, formulaic language, and role play, as a language learning strategy to teach } \\
\text { cognitive academic language in English for Specific Purpose classroom of a university. The } \\
\text { language ability acquired through brainstorming and reading sessions equipped the students for } \\
\text { the task of describing a two-wheeler. The task which made use of the formulaic language led } \\
\text { the engineering students to interact meaningfully and know the content for describing a two- } \\
\text { wheeler and write the description in a coherent paragraph. The stimulated usage of academic } \\
\text { language in a role play could scaffold the content and language learnt for successful retention } \\
\text { for effective Oral Academic Presentation (OAP). Although the results cannot be generalised, } \\
\text { students joining higher education in universities in ESL/EFL countries would be immensely } \\
\text { benefitted by this kind of teaching method. } \\
\text { Keywords: Engineering students; formulaic language; role play; task-based language teaching }\end{array}$}} \\
\hline & & \\
\hline $\begin{array}{l}\text { First Received: } \\
28 \text { March } 2018\end{array}$ & $\begin{array}{c}\text { Revised: } \\
\text { September } 2018\end{array}$ & 31 January 2019 \\
\hline \multicolumn{3}{|c|}{$\begin{array}{l}\text { How to cite (in APA style): } \\
\text { Rajeswaran, C. M. (2019). Task, formulaic language, and role play for developing ESL } \\
\text { students' academic language. Indonesian Journal of Applied Linguistics, 8, 536-544. } \\
\text { doi: } 10.17509 / \text { ijal.v8i3.15252 }\end{array}$} \\
\hline
\end{tabular}

\section{INTRODUCTION}

The ESL and EFL classrooms have been the trajectory for the research on task-based language teaching (TBLT) in the past three decades. TBLT has engendered opportunities for classroom interaction (Long 1989; Skehan, 1998). In classroom teaching, its focus has been on process-based syllabi designed to increase learners' actual language use for communicative purposes. Its premise is that tasks provide input and output processing necessary for language acquisition. Tasks are motivational, and task difficulties can be negotiated and fine-tuned for particular pedagogical purposes. In fact, it is motivated by a theory of learning (Richards \& Rogers, 2001). Multiple models of language inform it, and hence it can support cognitive language learning (Skehan, 1998; Robinson, 2001) TBLT has learnercentred approach (Ellis, 2003; Nunan, 1989; 2004; Richards \& Rogers 2001). Furthermore, TBLT appropriates content-based and meaning-based tasks, not just linguistic forms (Carless, 2002; Littlewood, 2007).

Research into post-task effects (Skehan \& Foster, 1997) has shown that interactive tasks, followed by post-task activity of re-doing a task publicly after the task has been done privately, or the requirement that learners transcribe one minute of their own task performance subsequent to the task itself, leads to significantly greater accuracy and gets stronger with time (Skehan, 2003). With experiential learning as a theoretical base for task-based learning for Nunan (2004), a task is learning by doing. Tasks can be used to elicit language production, interaction, negotiation of meaning, processing of input and focus on form, all of which are believed to foster second language acquisition (Branden, 2008) in ESL and EFL learners. 
TBLT underpins the need for lexical items in language use and learning for easy interpretation and understanding. Hence, the use of formulaic expressions seems handy to be helpful for ESL learners to be productive. The use of formulaic expressions has been on the increase in the development of the second language and has been termed as a bootstrapping mechanism into the L2 grammar that target like constructions come first, eventually forcing the grammar to catch up. The view that once the formulaic expressions are memorised they help in the induction of abstract grammatical constructions has been advocated by Ellis $(2003,2012)$ and Wray $(2000,2008)$. Contrary to this view is the one that as learners develop their language proficiency, their knowledge of syntax and lexis drives changes in the production of conventional expressions and multi-word expressions-formulaic expressions (Bardovi-Harlig \& Stringer, 2017). Nevertheless, the importance of formulaic expressions cannot be underestimated.

Tasks and formulas or chunks will have a cumulative effect on the learners' proficiency with role play as a scaffolding technique. Previous research shows that role plays have a definite edge on any other communicative language learning technique on account of their malleability to submit to any approach and methodology. Role plays as communicative tasks (Aliakbari \& Jamalvandi, 2010; Anderson, 2006) increased vocabulary of school children and university students and controlled their language anxiety in speaking. Role plays encourage students to reflect on their knowledge of a subject and to use appropriate concepts when articulating their response to the role play setting. Participating in a role play benefit learners cognitively because the roleplay tends to be more effective at embedding concepts and understanding in the long term memory of the students than monotonous teacher delivered lectures. Furthermore, the understood concepts can be applied for problem-solving or any other academic purpose when a future occasion demands (Alden, 1999). The use of role play in the higher education context help students creatively combine apparently dissimilar ideas in innovative ways, balancing left-brain focused language production, such as grammar, syntax, vocabulary, pronunciation and functional aspects and the right-brain focused affective or emotional experience (Dinapoli, 2009).

In the higher learning context of university education, the academic curriculum focuses not on basic communicative competence but on academic competence. Academic competence is the ability to handle academic language functions which include describing, explaining, informing, comparing, debating, persuading, evaluating, etc. (Chamot \& O'Malley, 1994). And hence, the ESL students should "have mastered basic skills in reading, writing, and computation and to understand and use increasingly abstract language" (Chamot \& O'Malley, 1987, p. 228) even before they left school, to cope with the demands of higher educations. Further, academic language is context reduced because it is mostly teacher lectured and supported by what is found in the textbooks themselves and cognitively demanding as the increasing grade levels introduce new information and new language items (Chamot \& O’Malley, 1987, 1996, 2009). Extensive authentic practice, i.e. in-classparticipation, such as taking part in discussions, interacting with peers and professors, and asking and answering questions, is what the academic learners need to excel in academic communication (Ferris \& Tagg, 1996a, 1996b). As such, the two-way dialogue between a teacher and learners as a classroom pedagogy, 'discourse socialisation' (Morita, 2000) and 'extension of conversation' (Bruner, 1990) is essential for 'academic learning' (Cummins, 1984). In the absence of 'zone of proximal development' (ZPD) - in a non-native environment, such practices help students to function from 'inter-mental' to an 'intra-mental' plain, i.e., as the students interact, they share knowledge among themselves to get it converted into individual knowledge (Vygotsky, 1978; Wertsch \& Kanner, 1992).

In addition, task-based interaction as a learnercentred communicative activity in a language classroom motivates the learners "to accomplish a task, and the pedagogical and interactional focus is on the accomplishment of the task rather than on the language used" (Seedhouse, 1999: p.150). On the same note, Tharp and Galimore (1989) as cited by Wells and Haneda, (2005: p.151) coined the paradoxical term 'instructional conversation: 'instruction' implying authority, (the act of teaching); 'conversation' implying making meaning and responding. Using instructional conversation as support to a pedagogical task, teachers and learners become active participants in the conversational discourse, the process of which includes teacher and learner elicited questions and responses. In this case, the target language becomes the vehicle for communicating ideas rather than an instructional tool (Pinkevičienè, 2011) to accomplish the task.

The present study attempts to add to the previous studies mentioned above, investigating how ESL learners could learn not ordinary, everyday language but the academic language in a classroom using a pedagogical task which is form focused; how formulaic expressions help the learners to express initially; and how role play helps them in cognition. In this study, the task-based academic language learning method is saddled with formulaic language to free the learners from the burden of learning grammar in a short period of time. Despite the contradictory notions of the earlier research, the present research made the formulaic expressions as a source of motivation and confidence building for the university learners in the context of their poor 'grammaring skill' (Freeman, 2003). Role play is used as a sequential scaffolding task in the process of cognition. Together, they give a valid experience to show how the trio of task, formulas and role play engage adult learners in learning oral academic presentation. 


\section{METHOD}

The efficacy of task-based instruction with the use of formulaic expressions for easy access to the use of vocabulary and structure and role play for cognition was investigated with teaching a section (control group) with traditional lecture method and the other section (experimental group) with task, formulas, and role play. At the end of class, both classes were assessed linguistically and communicatively for an oral academic presentation of describing a two-wheeler, writing an assessment of a short paragraph, and a role play performance with the learnt topic. Individual scoring was credited to group scoring. The groups' scoring accrued to the entire class scoring as the independent sample $t$-test scoring of the class. The $t$-test score of each class was statistically compared and analysed for 'p' value.

\section{Participants}

The study included two sections, Sections B and H, of first-year engineering students of Dr MGR Educational and Research Institute in Chennai. Each section comprised of sixty students. In view of their different cultural, lingual background and proficiency in English, they were heterogeneous. They were young adults in the age group of 18 to 20 years. They shared the common goal of academic excellence. As engineering students, they have already been introduced to basic engineering program and they were adept in drawing the sketches of instruments and tools. They were aware of the skills needed in Oral Academic Presentation (OAP). As for the proficiency level in English, there were excellent to the limited English proficient students. Many of them were not confident to participate in any academic programme, as they were apprehensive of their ability to use English for Oral Academic Presentations (OAP). Section B was taken as a control group and section $\mathrm{H}$ as an experimental group. Both classes were informed about the day's task of "Describing a two-wheeler" and its importance in the syllabus.

\section{Control class (Section B)}

The researcher gave a lecture in this class, detailing the different kinds of two-wheelers available in the market, how they look and how they function, with adequate information about their advantages and disadvantages. At the middle of her lecture, the students became restless as if the teacher was wasting her time on a known subject. The class was divided into twelve groups as per the roll call: 1-5, 6-10, 11-15 and so on. They were asked to work together in groups to write a paragraph 'Describing a Two Wheeler' in the next class. Each member of the group was to present his paragraph orally and submit the write up for evaluation. Then they were to perform a role play using the information about the two-wheeler of their choice. The leader of the group was to be the sales executive of a two-wheeler showroom, and the other four were customers interested in buying a two-wheeler. The students made a chorus of 'OK' and left.

\section{Experimental class (Section $\mathbf{H}$ )}

The experimental section was informed that the actual learning was task-based and that it would be different from their regular classroom activity of chalk and talk. The students were informed that they were going to learn the task of describing a two-wheeler. It will be a group activity to be followed by role play performance. The task was carried out in accordance with the concept of Willis and Willis (2007). The process of task-based learning was briefed as it was done in the control class, as follows:

\section{Grouping}

The idea was to make the learning a cooperative effort made by learners of heterogeneous abilities which could motivate and sustain their interest in learning. The students were asked to enlist the names of different two wheelers available in the market. The intention was to group the students in accordance with the vehicle of their choice. Then, they were slowly led to inform the class about the two-wheelers that they own. When many of them said they did not own any vehicle, the parents' or siblings' vehicles were considered their own. The students were then segregated in groups, in accordance with their vehicle ownership. But when certain groups exceeded the limit of five in a group and when certain groups lacked members, the teacher needed to shuffle the excess members to the thin groups. Thus, a class of sixty students was divided into twelve groups.

\section{Brainstorming}

Pre-task was brainstorming session which warmed up the students to drag them into lively competitive information disseminating and gathering activity. The activity was to increase their vocabulary count and use the vocabulary in the sentences to describe a twowheeler. The groups which gave more number of words were appropriately recognised with applause that a competitive spirit was built up in the class.

\section{Drawing and describing}

Brainstorming was followed by a drawing session to draw the vehicle and to name its parts. Then, a student was asked to draw a two-wheeler on the board, and he was prompted by the peers to mark the parts. The other students were asked to say and write down the parts, components, the colour, appearance, performance as advertised by the company like speed, mileage, fuel efficiency, etc. As the students said the words, the teacher wrote them on the board all the while eliciting, clarifying spelling and meaning, etc. The group which gave and wrote more number of words was adjudged the best, and a prize was hinted to motivate and excite students. At the end of the class, the students were asked to bring the authorised pamphlets and advertisements circulated by the distributors of the vehicles of their choice to be of some help for them to describe the vehicle in the next class. The individual groups also drew a diagram of the motorbike of their choice and marked the parts. 
An interactive session between the teacher and the students equipped the latter with appropriate vocabulary for the purpose of describing the principle, performance, appearance, advantages, and disadvantages of the bike.

\section{Interaction: Instructional conversation}

The teacher elicited answers through questions such as "How does a motorbike or scooter work?". Students then talked about two-stroke engines and four-stroke engines and other relevant details enthusiastically as appropriate to their age and interest; as many of them were from automobile engineering discipline, they could use the content knowledge in the conversation. In fact, one of the students was ready to show the diagram of a four-stroke engine and its operation and gave a rough idea about working principles as applicable to all vehicles.

The teacher also exploited instructional conversation by making enquiries on colour, the reason for being called as a two-wheeler, its appearance, utility, working principle, advantages, disadvantages, etc. When asked individually to describe the bike of their choice many became reticent. The teacher had to model the describing with formulaic expressions.

\section{Use of formulaic language}

What follows is the formulaic language used in the classroom:

This is my motorbike. I like it.

It is called Apache - It is manufactured by TVS/ Royal Enfield/ Ford etc., - It runs on petrol. It has a four stroke engine- it gets started with a kick/press of a button once started the bike keeps running-It has front and back brakes. They are useful in stopping and mitigating its speed.

As for its appearance

It is ___ (beautiful, sleek).

It is ___ (heavy/light). It weighs

approximately____ kilograms.

It is____ (black, red, green, azure

blue).

As for its parts: (vocabulary)

It has two wheels with scaffolding spokes, horn, handlebar, speed accelerator, brake, left and right indicator lights, lock and key, a side box to store things, petrol tank to store petrol, speedometer to monitor the speed, fuel indicator to show the availability of fuel, gear to control the speed, saree guard, etc.

As for its performance:

- It can be used anywhere; a fast mode utility vehicle.

- It is better than a bicycle in terms of speed and mobility.

- It is not eco-friendly.

- It pollutes the atmosphere by emitting carbon monoxide.

- I can avoid fatal road accident/ I can be safe by going slow and wearing a helmet.
- $\quad$ Obtaining a driving license is important to ride a bike on roads.

\section{Scaffolding activity: Writing a paragraph and enacting role play}

Students wrote down whatever they had researched by way of listening (brainstorming) and reading (pamphlets, advertisements) and the formulaic expressions that were given on board. Then, the students were to write a paragraph (200 words max.) about the two-wheeler of their choice with a title and content focusing on its definition, working principle, appearance (colour, metallic body, parts, etc.), advantages and disadvantages, and a final opinion (conclusion).

Students subsequently read aloud what they had written. Their write-ups showed the conscious attempt that they made in organising the ideas in the teachergiven order. Having been thorough with the content of their discourse, the students were to write a dialogue between a group of potential customers and the sales representative of a two-wheeler showroom.

\section{Role-play cue cards}

Student 1: you are a salesman at TVS Company. You are promoting its motorbike Apachi. Speak about its salient features.

Student 2, 3, 4, 5: You want to buy a motorbike. Enquire to know the details from the salesperson. Ask about its performance, fuel efficiency, price, finance facility, etc.

Role play activity is significant as a scaffolding technique to firm up the content knowledge and as a learning instrument for learning academic language functions. Repeat performance made them realise Taskbased Language Teaching (TBLT) as an accommodative method within the communicative approach to help the students negotiate the meaning and that the form focused activity was to acquire the language through 'consistent elicitation' (Brown \& Yule, 1983).

\section{Assessment}

The assessment and the feedback from the students could bring relevance to the previously established notions in English as a second language learning. Assessment on writing, oral presentations, and role play performances through work on a different plain in an academic context looks for effective describing, explaining, informing, comparing, debating, persuading, evaluating, etc. from the students (O'Malley \& Pierce, 1996). The twelve groups in each of the classes were assessed for their Written Passage, Oral Academic Presentation, and role play performance.

As O'Malley and Pierce (1996) suggest, the students' written passages were given differentiated scoring for content knowledge in terms of describing the two-wheeler (working principle, appearance, utility, 
advantages, and disadvantages) and language conventions which looked for apt vocabulary, structure and coherence in building the paragraph. Though written and oral presentation assessments were individual, each member's mark was credited to the group account and accumulated mark was the mark of the group. The overall mark was the group score for written passage and oral presentation. Role play assessment was a group assessment.

The speaking construct for the assessment included linguistic criteria to focus on language forms, and communicative skills of the examinees and their performance was assessed to find how well they used the skills and strategies that the activity required and also how well they used the information the tasks were designed to reveal (Luoma, 2004).

An evaluation was done with the rubrics suggested by role play communicative assessment (Adapted from Bjornstad \& Karolle, 2000 by Chandrasena, 2017) and cognitive academic language assessment adapted from O’Malley and Pierce (1996) by Chandrasena (2017). The writing assessment rubrics were adapted from O'Malley and Pierce (1996). At the end of the assessment, the scores of both classes were subjected to independent sample $t$-test analysis to compare their performance statistically.

\section{RESULTS}

All the twelve group members of the experimental group made the oral presentation with their write-ups in their hands. However, barring a few limited English proficient students, others did not refer to the write-ups, which showed their short term memory was active. The write-ups were submitted for evaluation. Oral Academic presentation was also evaluated quantitatively. As for the role plays, the students enjoyed writing the script for the role play with peer assistance. When they plunged into role play performance, the students fitted well into the characters and spoke the dialogue with not much of external prompt, which showed the paragraph and script writing helped them cognitively.

Meanwhile, for the control group, despite their perception of describing a two-wheeler as a very easy task and their confidence in their ability to write well, they could not produce writing that meets the criteria of academic writing, especially in the use of appropriate vocabulary in well-knit (cohesive) structures. Being lazy and lacking motivation, the students simply indulged in copying and submitted the assignments. When they were asked to present orally of what they have written, all of them, excepting ten students became reticent. However, they were forced to present orally, and their poor marks were recorded and attributed to group score. As for roleplay performance, only ten students came forward to enact the role play of selling a two-wheeler. So, they were permitted to perform as two groups, and their marks were recorded.

The results of the assessment for the two groups were then compared with a $t$-test. The quantitative scores were transcribed in independent sample $t$-test to find the comparison between the control and experimental groups. The test scores of both sections were compared based on their mean scores and standard deviations to find the probability value contrasted with the level of significance. The results for $t$-test analyses on the assessments of writing a paragraph and oral academic presentation are presented in Table 1 and Table 2. Meanwhile, the scores for role play performance were not statistically compared, as the number of participating groups in both classes was not equal. As stated before, only two groups were willing to perform in the control class, while all groups in the experimental class came forward to perform role play.

Table 1. Independent sample $t$-test result analysis for the written paragraph

\begin{tabular}{clcccccc}
\hline Task & \multicolumn{1}{c}{ Group } & N & Mean & Std. Deviation & t value & $\begin{array}{c}\text { Sig. } \\
\text { value }\end{array}$ & Result \\
\hline \multirow{2}{*}{ Writing a paragraph } & Control Class & 12 & 33.17 & 17.49 & -7.415 & 0.000 & Significant \\
& Experimental Class & 12 & 75.33 & 9.07 & & \\
\hline
\end{tabular}

Table 2. Independent sample $t$-test result analysis for oral academic presentation (OAP)

\begin{tabular}{lllccccc}
\hline \multicolumn{1}{c}{ Task } & \multicolumn{1}{c}{ Group } & N & Mean & Std. Deviation & t value & $\begin{array}{c}\text { Sig. } \\
\text { value }\end{array}$ & Result \\
\hline Oral Academic & Control Class & 12 & 24.92 & 16.24 & -8.314 & 0.000 & Significant \\
Presentation & Experimental Class & 12 & 72.50 & 11.36 & \\
\hline
\end{tabular}

Table 1 shows that the ' $p$ ' value of 0.000 is less than 0.01 , which is significant at $1 \%$ level. It is concluded then that there was a significant difference between the control class and experimental class in the written test. The mean value of the control class and experimental class were 33.17 and 75.33 , respectively. The experimental class scored higher than the control class in academic writing.

Based on the results displayed in Table 2, it is revealed that the ' $p$ ' value of 0.000 is less than 0.01 , which is significant at $1 \%$ level. This result means that there was a significant difference between the control class and experimental class in oral presentation. The mean value of the control class and experimental class were 24.92 and 72.50, respectively. The experimental class had greater scores than the control class in oral academic presentation.

\section{DISCUSSIONS}

The present research could promulgate the ability of task-based activity to lead the learners unconsciously to 
negotiate the meaning in meaningful conversations if the context suits the learners' knowledge and proficiency level. The young adult learners' interest in the two-wheelers was exploited to make them do a task and speak. The result of this task-based research connotes with that of Lytovchenko (2009).

An interaction between the teacher and students, the kind of language or discourse and socialization that culminated in elicitation of information and performance thereafter was useful in reducing the classroom rigidity and anxiety in expressions of the students. The 'task-based interaction' (Seedhouse, 1999), as it happened in the classroom during and after brainstorming, interpreting the advertisement pamphlets, and debates in terms of asserting the advantages of chosen vehicles proved the advantages of instructional conversation. As Reveles (2004) explains, the students spoke more than the teacher; the teacher, therefore, became a listener and facilitator. Hence it proved "Instructional conversation protocol is a way to transform a classroom into a more productive learning community through dialogic teaching" (Reveles, 2004, p.1).

Furthermore, the informed and transparent task process made the learners realise learning can be achieved only by their own willing participation. In this context, Rifkin's (2000) view that learners' perceptions about the learning process are of critical importance to the success or failure of any student's effort to master a foreign language needs to be recorded.

In terms of formulaic language, it is interesting to compare the results of the present research to those of Fillmore (1976). Fillmore (1976) could make little children memorise formulas for social relations and as linguistic material seeding their acquisition of grammar for productive use later. Meanwhile, the research participants of this research were 18-20 year old. The participants could not structure their linguistic expressions with grammar, which is an important component in the academic language. Hence, their learning of grammar was circumvented with the formulaic language to be permuted in different contexts. The context reduced input found in the printed materials became comprehended input by way of discussion, and when they had to be expressed orally and in writing, the formulaic language helped them. The repeated use of formulas in writing and role play fortified them in the students' schema for automatic use later, at a time of need. Formulas usage supports Bardovi-Harlig's and Stringer's (2017) findings that formulas get stored with conventional phrases in long term memory.

'Controlling the vocabulary learning' is a second language learning paradigm which has helped the autonomous learners to shed off a load of learning a large number of corpora which may not be fully relevant to their academic needs. The students' attention was focused on their primary needs of specific vocabulary, and the learning process was circumvented. Schmitt (2008) talks about how words get connected to one another in mind. The 'word associations' as identified by Schmitt have a psychological bearing and a stimulus word pertaining to the knowledge of the students. They can also bring typical responses which are automatic and exhibit a strong connection with the stimulus word. The number of words that the students could bring in describing their favourite or dream vehicle stands as proof for Schmitt's analogy.

It is also worth noting that the mental maturity of the learners makes a large difference in understanding the relevance and relationship to the stimulus word. This, again, justifies Hilles' and Sutton's (2001) view of adult learners as voluntary learners and that they bring cognitive maturity to the classroom. Hence, as it happened in this particular classroom, the mental lexicon when organised meaningfully become paradigmatic, which indicates the general evolution of lexical organisation patterns as a learner's language matures and not stored at random in mind (BardoviHarlig \& Stringer, 2017).

Another important aspect to discuss is vocabulary. Vocabulary is manipulated in different ways by skilled speakers and writers as they create and construct coherent discourse to create various emotive effects Schmitt (2008). The discourse markers and prepositional phrases are multiword units that fall under the category of a string of words when used as a pattern in the different and similar syntactic structure, with repeated usage raised consciousness about the word usage and its associated structure. This was evident in the scripts written by the students in groups. This is what Schmitt (2008) calls 'threads of lexis in conversation,' which allows the avoidance of repetition and establishment of lexical cohesion.

With regard to formulaic expressions, in the initial stage, the students were producing fixed, invariable formulas (chunks), but in repeated use, they utilized what Ellis (2003) terms 'low-scope patterns' (frames with open slots), before finally having a system of sophisticated constructions (productive, abstract schema), what Ellis (2003) considers to be the equivalent of a grammar. Formulaic expressions made the students feel less stressed for words and grammar. The fact that a number of grammatically acceptable variants of formulaic expressions are used in particular contexts to perform particular functions denotes that form and function are closely related, hence substantiating the views of Pawley and Syder (1983). A few students in this research could not hold the formulaic expressions in their sentence structures and stammered. It proved that the short term memory constraints limit the number of individual units speakers can hold, and hence their fluency suffered a setback (Guillaume, 1973). Nevertheless, the participants could give a better-written assignment on the topic but no less oral output in the form of excellent role play.

The role play performances which relied solely on the students' intake of the input served through reading, instructional conversations, discussions, brainstorming, and formulaic language gave the learners an opportunity to use apt vocabulary in accurately structured sentences 
that students could overcome the inhibitions of selfconsciousness and language anxiety. Through impersonation, the students have divested themselves of the responsibility for personal mistakes. The students seemed to have acquired a new and confident personality and wished for more such role-play exercises. The role-playing performance proved that "role-playing and language learning may be very intimately connected and role-playing exercises should be given the importance they deserve" (Dobson 2005, p. 48)

In this study, the approach was not one but a combination of different methodologies. It made use of the audio-lingual when the formulaic language was used to shorten their learning period so as to fit into three periods of fifty minutes each. Interactive learning was used to gather information. Cooperative learning was introduced to give more time for the students to get engaged in discussions, to reflect, think, and to arrive at a decision to do the academic functions in collaboration. The groups competed against each other in the brainstorming sessions for the required vocabulary. The cooperative group learning could transform 'input into intake' and then into 'comprehensible output' (Long, 1985). A structured cooperative task as it was, the learners contributed to the 'discourse socialisation' (Morita, 2000) in the process, and each student looked forward to more such tasks to engender opportunities.

However, the negative aspect of the group assessment, as realised in this particular study, needs to be recorded. Group reports or assignments are considered to be problematic because they involve merging diverse skills and personalities with the hope that they will collaborate towards a common goal (Kruck \& Reif, 2001). Grouping in a heterogeneous class is not a problem, but group assessment is. It was clearly evident in the control class's written assessment. There were about twenty averagely and above averagely proficient students in the control class. When individual members' marks were accrued to make group mark, groups failed because all team members were either not able or not willing to contribute equally to the team's success. The poor performance must surely be attributed to the self-perception of their ability to write a paragraph and not willing to learn. Further, the traditional kind of lecturing failed to motivate learners to participate in learning.

\section{CONCLUSION}

Despite being heterogeneous, in terms of their English language proficiency, culture and mother tongue, the results of this research have confirmed that the engineering students have held a positive attitude towards using task, formulaic language, and contentembedded role play activity and hence their success. The three research questions on the efficacy of task, formulaic language, and role play have received a positive reply. The present research, which had encompassed Willis' and Willis' task process (2007) within the framework of communicative language teaching and cognitive academic language approach, was successful in motivating the engineering students for an academic oral presentation. Hence it is hoped that more such action research and classroom research of pedagogic interests will be successfully generated in the institutes of higher learning as long as the teachers are well prepared and the students are willing to learn. It may also be noted that the study was limited to a limited number of first-year engineering students of Dr. M.G.R. Educational and Research Institute in Chennai; hence, the results cannot be generalized, although the implications may apply for ESL teaching and learning of academic language in general.

\section{REFERENCES}

Alden, D. (1999). Experience with scripted role play in environmental economics. The Journal of Economic Education, 30(2), 127-132. doi:10.1080/00220489909595949

Aliakbari, M., \& Jamalvandi, B. (2010). The Impact of role play on fostering EFL learners' speaking ability: A task-based approach. Pan Pacific Association of Applied Linguistics, 14(1), 15-29.

Anderson, J. (2006). Role plays for today: Activities to get students speaking. New Delhi: Viva Books.

Bardovi-Harlig, K., \& Stringer, D. (2017). Unconventional expressions: Productive syntax in L2 acquisition of formulaic language. Second Language Research, 33(1) 61-90. doi: $10.1177 / 0267658316641725$

Bjornstad, J., \& Karolle, K. J. (2000). Using group roleplay to test speaking: Setting up a Wohngemeinschaft. Teaching German, 33(2),134137. doi: $10.2307 / 3531562$

Branden, K.V.D. (2008). Task-based language education: From theory to practice. Cambridge: Cambridge University Press.

Brown, G \&Yule, G. (1983). Teaching the spoken language: An approach based on the analyses of conversational English. Cambridge: Cambridge University Press.

Bruner, J. S. (1990). Foreword. In R. Grieve \& M. Hughes (eds.). Understanding children. Oxford: Basil Blackwell.

Carless, D. (2002). Implementing task-based learning with young learners. ELT Journal, 56(4), 389-396. doi: 10.1093/elt/56.4.389

Chamot, A. U. \& O’Malley, J. M. (1987). The cognitive academic language learning approach: A bridge to the mainstream. TESOL Quarterly, 21(2), 227-241. doi: 10.2307/3586733

Chamot, A. U. \& O’Malley, J. M. (1994). The CALLA handbook: Implementing the cognitive academic language learning approach ( $2^{\text {nd }}$ edn.). New York: Addison-Wesley Longman,

Chamot, AU \& O’Malley, J.M. (1996). Implementing the cognitive academic language learning approach. In R. Oxford (ed.), Language learning 
strategies around the world: Cross-cultural perspectives (pp.108-113). Manoa: University of Hawaii Press.

Chamot, A. U. (2009). The CALLA handbook: Implementing the cognitive academic language learning approach, second edition. White Plains, NY: Pearson Education/ Longman.

Chandrasena, M.R. (2017). Enhancing oral communication skills of engineering students through role play (Doctoral Dissertation). Dr MGR Educational \& Research Institute, Chennai.

Cummins, J. (1983). Conceptual and linguistic foundations of language assessment. In S. S. Seidner (ed.) Issues of language assessment: Vol.2. Language assessment and curriculum planning (pp. 7-16). Wheaton, MD: National Clearing House for Bilingual Education.

Cummins, J. (1984). Bilingual education and special education: Issues in assessment and pedagogy. San Diego: College Hill

Dobson, J.M. (2005). Effective techniques for conversational groups. Rowley Massachusetts: Newbury House Publishers.

Ellis, N. C. (2003). Constructions, chunking, and connectionism: The emergence of second language structure. In C. Doughty \& M. H. Long (eds). Handbook of second language acquisition (pp. 3368). Oxford: Blackwell.

Ellis, N. C. (2012). Formulaic language and second language acquisition: Zipf and the phrasal teddy bear. Annual Review of Applied Linguistics, 32, 17-44. doi: 10.1017/S0267190512000025

Ellis, R. (2003). Task-based language teaching and learning. Oxford: Oxford University Press

Ferris, D., \& T. Tagg. (1996a). Academic oral communication needs of EAP learners: What subject matter instructors actually require. TESOL Quarterly, 30(2), 31-55. doi: 10.2307/3587606

Ferris, D., \& T. Tagg. (1996b). Academic listening/speaking tasks for ESL students: Problems, suggestions and implications. TESOL Quarterly, 3(2), 297- 317 doi: 10.2307/3588145

Fillmore, L. W. (1976). The second time around: Cognitive and Social Strategies in Second Language Acquisition (Doctoral Dissertation). Stanford University, USA.

Freeman, D. L. (2003). Teaching language: From grammar to grammaring. Boston: Thomas Heinle.

Guillaume, P. (1973). First stages of sentence formation in children's speech. In C. A. Ferguson \& D. I. Slobin (Eds.), Studies of child language development. New York: Holt, Rinehart \& Winston.

Hilles, S., \& Sutton, A. (2001). Teaching Adults. In M. C. Murcia (ed.) Teaching English as a second or foreign language (pp. 385-399). Boston, Mary Land: Thomson Learning.

Kruck, S. E., \& Reif, H. L. (2001). Assessing individual student performance in collaborative projects: A case study. Information Technology, Learning, and Performance Journal, 19(22), 37-47.

Littlewood, W. (2007). Communicative and task-based teaching in East Asian classrooms. Language

Teaching, 40(3), 243-249. doi: 10.1017/S0261444807004363

Long, M. (1985). A role for instruction in second language acquisition: Task-based language training. In K. Hyltenstam \& M. Pienemann (eds.) Modelling and assessing second language acquisition (pp. 77-99). Clevedon, UK: Multilingual Matters.

Long, M. (1989). Task, group, and task-group interaction. University of Hawaii Working Papers in English as a Second Language, 8(2), 1-26.

Luoma, S. (2004). Cambridge language assessment series: Assessing speaking ( $1^{\text {st }}$ edn.). Cambridge: Cambridge University Press.

Lytovchenko, I. (2009). How to make upper level university English classes more interactive. English Teaching Forum, 47(2), 24-29.

Morita, N. (2000). Discourse socialisation through oral classroom activities in a teaching English as a graduate program. TESOL Quarterly, 34(2), 279310. doi: $10.2307 / 3587953$

Nunan, D. (1989). Understanding language classrooms: A guide for teacher initiated action ( $2^{\text {nd }}$ edn.). London: Prentice Hall.

Nunan, D. (2004). Task-based language teaching. Cambridge: Cambridge University Press.

O’Malley, J. M., \& Pierce, L. V. (1996). Authentic assessment for English language learners: Practical approaches for teachers. USA: Addison Wesley.

Pawley, A. \& Syder, F. (1983). Two puzzles for linguistic theory: native like selection and native like fluency. In J. C. Richards \& R. Schmidt (eds.) Language and communication. London: Longman.

Pinkevičienè, D. (2011). Triadic dialogue in EFL classroom: Embedded extensions. Kalbu Studijos, 18, 97-104.

Reveles, J. (2004). Instructional conversation in middle school setting. Language, Literacy, Learning, 1-12

Richards, J.C. \& Rodgers, T. (2001). Approaches and methods in language teaching, ( $2^{\text {nd }}$ edn.). Cambridge: Cambridge University Press.

Rifkin, B. (2000). Revisiting beliefs about foreign language learning. Foreign Language Annals, 33(4), 394-409. doi: 10.1111/j.19449720.2000.tb00621.x

Rivers, W. M. (1987). Interactive language teaching. Cambridge: Cambridge University Press.

Schmitt, N. (2008). Aspects of knowing a word: Meaning and organization \& vocabulary in discourse. In J.C. Richards (ed.) Vocabulary in language teaching (pp. 22-115). Cambridge: Cambridge University Press

Seedhouse, P. (1999). Task-based interaction. English Language Teaching Journal, 53(3), 149-156. doi: 10.1093/elt/53.3.149 
Skehan, P. (1998). A cognitive approach to language learning. Oxford: Oxford University Press.

Skehan, P. (2003). Task-based instruction. Language Teaching, 36, 1-14. doi: 10.1017/S026144480200188X

Skehan, P. \& Foster, P. (1997). The influence of planning and post-task activities on accuracy and complexity in task based learning. Language Teaching Research, 1(3), 185-221.

Tharp, R., \& Gallimore, R. (1989). Rousing minds to life. New York: Cambridge University Press.

Vygotsky, L. (1978). Mind in Society: The development of higher psychological process. Cambridge, MA: Harvard University Press.

Wells, G., \& Haneda, M. (2005). Extending the Instructional Conversation. In C. R. O'Donnell \& L. Yamauchi (Eds.) Culture and Context in Human
Behavior and Change: Theory, Research, and Applications (pp. 151-178). New York: Peter Lang.

Wertsch, J. V., \&Kanner, B.G. (1992). A sociocultural approach to intellectual development. In R. J. Sternberg \& C. A. Berg (eds.). Intellectual development. Cambridge: Cambridge University Press.

Willis, D. \& Willis, J. (2007). Doing task-based teaching. Oxford: Oxford University Press.

Wray, A. (2000). Formulaic sequences in second language teaching: Principles and practice. Applied Linguistics, 21(4), 463-489. doi: 10.1093/applin/21.4.463

Wray, A. (2008) Formulaic language: Pushing the boundaries. Oxford: Oxford University Press.

\section{APPENDIX \\ Role play communicative assessment \\ (Adapted from Bjornstad\&Karolle (2000) by Chandrasena, 2017)}

Total Points: 50

The rating for the communicative assessment included: (10 points each)

1. Understands others well enough to be able to respond in English appropriately.

2. Accurate and fluent enough to be easily understood.

3. Demonstrates a command of vocabulary and structures appropriate to role play

4. Displays appropriate gestures and maintains eye contact.

5. In the face of communication breakdowns, manages to negotiate meaning.

\section{Cognitive academic language assessment \\ (Adapted from O'Malley and Pierce (1996) by Chandrasena, 2017)}

Total points: 50

The rating for the academic communicative assessment included: (10 points each)

1. Understanding unfamiliar oral and written texts by using prior knowledge

2. Expressing knowledge orally with appropriate vocabulary and syntax.

3. Formulating questions and produces/gathers information.

4. Generating ideas for writing script, selects appropriate situation and register for the delivery.

5. Describing, comparing and contrasting effectively.

\section{Cognitive academic language assessment \\ (Adapted from O'Malley and Pierce (1996) by Chandrasena, 2017)}

Total points: $\mathbf{5 0}$

The rating for the academic writing assessment included: (10 points each)

1. Description of the object/ concept/ Working principle

2. Utility/advantages/disadvantages

3. Apt vocabulary

4. Structure

5. coherence 